\title{
Aspek Kepribadian Tokoh Utama dalam Kumpulan Cerpen Jurig Paséa jeung Nyi Karsih Karya Tini Kartini
}

\author{
Gita Kurnia Déwi ${ }^{1}$, Ruhaliah ${ }^{2}$, Retty Isnendes ${ }^{2}$ \\ ${ }^{1}$ SMKS Al Farisi Garut, ${ }^{2}$ Universitas Pendidikan Indonesia \\ gitakurniadewi@gmail.com
}

\begin{abstract}
Sejarah Artikel: Diterima (25 Maret 2019); Diperbaiki (30 April 2019); Disetujui (20 Juni 2019); Pusblished (31 Oktober 2019)

Bagaimana mengutip artikel ini (dalam gaya APA): Dewi, G. K., Ruhaliah, Isnendes, R., (2019). Aspek Kepribadian Tokoh Utama dalam Kumpulan Cerpen Jurig Paséa jeung Nyi Karsih Karya Tini Kartini. Lokabasa, 10(2). 131-141. doi: 10.17509/jlb.v10i2.21359
\end{abstract}

\begin{abstract}
Abstrak: Penelitian ini dilatarbelakangi oleh adanya konflik kepribadian para tokoh utama dalam kumpulan cerpen Jurig Paséa jeung Nyi Karsih. Teori yang digunakan dalam penelitian ini yaitu teori struktural Todorov dan teori psikologi sastra Jacques Lacan. Penelitian ini bertujuan untuk menganalisis dan mendeskripsikan: 1) struktur kumpulan cerpen Jurig Paséa jeung Nyi Karsih, 2) aspek kepribadian para tokoh utama dalam kumpulan cerpen Jurig Paséa jeung Nyi Karsih, dan 3) faktor yang mempengaruhi kepribadian tokoh utama. Metode yang digunakan dalam penelitian ini adalah metode deskriptif analisis. Sumber data penelitian ini adalah kumpulan cerpen Jurig Paséa jeung Nyi Karsih karya Tini Kartini. Teknik pengumpulan data dengan menggunakan teknik studi pustaka. Teknik dalam mengolah data yaitu menggunakan teknik analisis secara langsung. Adapun instrumen dalam penelitian ini menggunakan instrumen tabel dan kartu data analisis. Hasil penelitiannya yaitu, pertama, struktur cerita dalam kumpulan cerpen Jurig Paséa jeung Nyi Karsih dibuat dengan lengkap, artinya dibentuk oleh aspek sintaksis dan semantik yang menyeluruh, serta ceritanya menggambarkan imajinasi yang dikuatkan oleh kesadaran dalam sejarah masarakat dan kehidupan dahulu. Kedua, aspek kepribadian tokoh utama bisa dianalisis dengan jelas berdasarkan hasil kebutuhannya (yang nyata), kekurangannya (yang imajiner), dan hasrat keinginannya (yang simbolik). Ketiga, kepribadian tokoh utama bisa dianalisis karena adanya faktor-faktor yang mempengaruhi kepada kepribadian tokoh utama yang terdiri atas faktor internal dan faktor eksternal. Kesimpulannya, kumpulan carpon Jurig Paséa jeung Nyi Karsih mempunyai aspek kepribadian tokoh utama dengan adanya unsur kejiwaan tokoh utama dan faktorfaktor yang mempengaruhi kejiwaan pada kepribadian tokoh utama.
\end{abstract}

Kata Kunci: kumpulan cerpen; struktur; aspek kepribadian; faktor kepribadian

\section{Personal Aspect of the main Character in Short Story Collection Jurig paséa jeung nyi karsih by tini kartini}

Abstract: The background of the research is the personality conflict of the main characters in the short story collection Jurig Paséa jeung Nyi Karsih. The theory used in this study is Todorov's structural theory and Jacques Lacan's literary psychological theory. This research aimed to analyze and describe: 1) the structure the short story collection Jurig Paséa jeung Nyi Karsih, 2) the personality aspects of the main characters in the short story collection Jurig Paséa jeung Nyi Karsih, and 3) factors that influence the personality of the main character. The method used in this research is descriptive analysis method. The data source of this research is a short story collection Jurig Paséa jeung Nyi Karsih by Tini Kartini. Data collection techniques using a literature study technique. The techniques in processing data are using direct analysis techniques. The instruments in this research use table instruments and data analysis cards. The results of the research are, first, the structure of the story in the short story collection Jurig Paséa jeung Nyi Karsih made completely, it is formed by the whole syntactic and semantic aspects, 
and the story illustrates the imagination that is strengthened by consciousness in the history of the community and life. Second, the personality aspects of the main character can be clearly analyzed based on the results of their (real) needs, their deficiencies (which are imaginary), and their desires (which are symbolic). Third, the personality of the main character can be analyzed because of the factors that influence the personality of the main character consisting of internal factors and external factors. In conclusion, the short story collection of Jurig Paséa jeung Nyi Karsih has the personality aspect of the main character in the presence of the psychiatric element of the main character and the factors that influence the personality of the main character's personality.

Keywords: short story collection; structur; personal aspect; personality factors

\section{PENDAHULUAN}

Permasalahan kepribadian manusia bisa menjadi ide atau gagasan untuk seorang pengarang dalam menghasilkan sebuah karya sastra. Kepribadian manusia menjadi gambaran dalam menghasilkan tokoh fiksional yang menceritakan jenis-jenis gangguan kejiwaan. Gangguan kejiwaan tokoh, tergambar dalam kumpulan cerpen Jurig Paséa jeung Nyi Karsih karya Tini Kartini. Para tokoh utama dalam cerpencerpen tersebut banyak yang mengalami peristiwa yang tidak menyenangkan. Dalam cerpen "Jurig" misalnya, Nyi Iyot disakiti oleh suaminya yang mengakibatkan seperti orang yang kurang waras atau setres. Begitu pun dalam cerpen "Ondangan", tokoh kuring yang merasa sudah membuat dosa karena mempunyai suami yang pernah jadi pacar temannya. Dalam cerpen "Sial", tokoh kuring merasa malu waktu ikatan rambutnya jatuh di depan banyak orang, sama halnya seperti tokoh kuring dalam cerpen "Di Lembur" yang dikenal oleh ibu-ibu di kampugnya sebagai orang yang tidak bisa mengaji. Cerpen "Nyi Karsih" juga menceritakan kehidupan yang buram, mengisahkan Nyi Karsih yang dipaksa melayani keinginan Juragan Dalem, sampai di akhir cerita Nyi Karsih bunuh diri. Dilihat dari isi ceritanya yang kompleks dan konflik jiwa yang dialami oleh para tokoh utama, menjadikan adanya aspek kepribadian yang menarik dalam cerpen ini.

Kumpulan cerpen Jurig Paséa jeung Nyi Karsih karya Tini Kartini terdiri atas 16 judul. Dalam tulisan peengantarnya, Hawé Setiawan, menyebutkan dalam buku kumpulan cerpen Jurig Paséa jeung Nyi Karsih awalnya merupakan kumpulan cerpen terpisah. Pertama ada "Jurig" (1963), disusul oleh "Paséa" (1965), dan "Nyi Karsih" (1976). Sekarang ketiga secita tersebut disatubukukan, jadi kumpulan cerpen Jurig Paséa jeung Nyi Karsih karya Tini Kartini. Taun 2003, Tini dianugrahi Hadiah Sastra Rancagé, berdasarkan jasa-jasanya yang sudah melestarikan bahasa dan sastra Sunda.

Untuk kepentingan penelitian ini, kumpulan cerpen yang ditelusuri ada 12 judul. Kumpulan cerpen ini dipilih karena aspek kepribadian tokoh utama sebagai bagian masalah yang diangkat oleh pengarang. Oleh karena itu, kepribadian para tokoh utama dalam kumpulan cerpen Jurig Paséa jeung Nyi Karsih karya Tini Kartini menjadi alasan untuk diteliti. Selain adanya kompleksitas kepribadian yang dianggap bisa memberikan gambaran untuk masyarakat jaman sekarang mengenai kehidupan jaman dahulu yang tidak pernah teralami, serta memberikan contoh mengenai kepribadian yang baik dan yang sebaliknya. Dengan begitu, cerpencerpennya bisa membangkitkan kesadaran banyak orang untuk mengetahui kehidupan secara rinci.

Peran pengarang sangat penting dalam mengungkapkan sebuah karya. Pengarang membuat alur dan tokoh fiksional dalam cerita, sampai karyanya bisa diterima oleh masyarakat. Pengarang bisa mendeskripsikan keadaan yang belum pernah dialami oleh masyarakat jaman sekarang melalui karyanya. Hal itu ditunjukkan oleh Tini Kartini. Dalam menulis kumpulan cerpen Jurig Paséa jeung Nyi Karsih, pengarang umumnya 
menceritakan hal-hal yang terjadi pada jaman dahulu, khususnya taun 60/70-an. Tini Kartini mengawali kepenulisannya tahun 1959, waktu itu Tini menyajikan sajak dan carita pondok (cerpen) dalam koran Sipatahoenan. Kelebihan pengarang ini terutama pada menulis cerpen, yang karya-karya dianggap berkualitas. Bahkan Tini pun pernah menjadi ketua Patrem, organisasi yang mempersatukan kaum perempuan yang memiliki hobi menulis dalam bahasa Sunda (Hawé Setiawan dalam Kartini, 2003, hlm. 6).

Dalam karya sastra, masyarakat mengaktualisasikan diri melalui modelmodel kehidupan masyarakat di dalam karya. Model-model ini terbelenggu oleh fiksionalitas (Isnendes dan Ucu, 2013, hlm. 85). Watt dalam Faruk (2013, hlm. 4) mengemukakan bahwa tokoh fiksional yang ada dalam karya sastra merupakan gambaran dari kehidupan manusia yang nyata. Begitu juga dalam kepribadian tokoh fiksi, misalnya pembaca memahami bahwa tokoh-tokoh mengalami gangguan kejiwaan, akan mempengaruhi cerita fiksi seterusnya maupun tokoh-tokoh yang ada di sekitarnya (Wiyatmi, 2011, hlm. 2).

Setiap manusia mempunyai kepribadian yang berbeda dari manusia lainnya. Menurut Minderop (2016, hlm. 6), kepribadian yaitu kualitas nalar dan karakteristik manusia yang sudah terbentuk, serta menjadi satu pola yang pasti dan mampu membedakan antara individu dengan individu lainnya. Kepribadian manusia bisa dilihat dalam beberapa hal, di antaranya dari ucapan, tingkah laku, serta sikap mentalnya. Dari tingkah laku dan sikap mental yang dilihatkannya, manusia mampu menentukan mana yang baik dan mana yang buruk. Begitu juga dengan penilaian terhadap manusia, antara yang pantas dihormat dan yang tidak, ditentukan oleh tingkah laku dan sikap mental dirinya.

Salah satu pendeketan sastra yang berhubungan dengan aspek kejiwaan yaitu psikologi sastra. Dasarnya, psikologi sastra menceritakan hal yang berhubungan dengan unsur-unsur kejiwaan tokoh fiksional yang ada pada karya.

Menurut Endraswara (dalam Jusriani 2015, hlm. 2), psikologi sastra yaitu kajian sastra yang mengemukakan bahwa karya sebagai aktifitas kejiwaan. Pengarang akan menggunakan cipta, rasa, karya, dalam menciptakan sebuah karya. Begitu juga pembaca, dalam merespon karya sastra tidak lepas dari kejiwaan masing-masing. Sebagai dunia, karya sastra di dalamnya mengandung aspek kehidupan, khususnya manusia. Psikologi sastra mempunya tujuan untuk menulusuri permasalahan kejiwaan dalam pengetahuan aspek-aspek yang ada dalam karya sastra (Ratna dalam Rakhman, 2013, hlm. 343).

Tokoh-tokoh yang ada dalam karya sastra mempunyai peran untuk menghidupkan sebuah kejadian dalam cerita (Sumarwati jeung Raheni, 2012, hlm. 179). Seperti halnya kepribadian manusia, tokoh-tokoh dalam karya sastra mempunyai kepribadian yang berbeda, hal ini dibutuhkan pendekatan psikologi untuk lebih memahami kepribadian (Zaelani, 2015, hlm. 2).

Aspek kepribadian manusia berdasarkan struktur kepribadiannya masing-masing dapat ditelusuri menggunakan pendekatan psikologi sastra. Menurut Lacan dalam Bracher (2018, hlm. $\mathrm{xx}$ ) kepribadian manusia bisa terlihat dalam beberapa hal, yaitu yang nyata (kebutuhan), yang imajiner (kekurangan), dan yang simbolik (hasrat). Menurut Lacan dalam Lechte (2001, hlm. 116) kepribadian manusia terdiri atas tiga aspek, yaitu imajiner yang berhubungan dengan dunia ilusi atau imajinasi, simbolik merupakan tempat atau barang yang mempunyai fungsi untuk mewakili pikiran dan objek, serta kenyataan (real) di mana manusia mempunyai pengalaman yang secara emosi menjadi dasar yang kuat. 
Dalam menguatkan aspek kepribadian tokoh utama yaitu dengan adanya faktor-faktor yang mempengaruhi kepribadian, yang terdiri atas faktor internal dan faktor eksternal. Kepribadian merupakan salah satu aspek dalam pendekatan psikologi sastra. Contoh penelitian seperti ini dilakukan oleh Jacques Lacan, yang menganalisis psikologi sastra melalui strukturalisme (Minderop, 2016, hlm. 23).

Menurut kaum strukturalisme, teks sastra yaitu totalitas yang dibentuk secara koherensi oleh semua unsur bentuknya (Nurgiyantoro, 2013, hlm. 57). Strukturalisme awalnya dipengaruhi oleh teori linguistik modern, hal ini menjadi model dalam wilayah kritik dan jadi bagian besar di Perancis. Sebagian strukturalisme Perancis menganalisis struktur karya sastra dalam model sintaksis kalimat, yang terdiri atas unsurunsur fungsinya sebuah karya sastra serta sesuai dengan kaidah-kaidah kalimat, seperti kata benda, kata kerja, dan kata sifat. Strukturalisme Perancis juga membedakan lapisan fonologik, metrik-ritmik, sintaksis, dan semantik untuk mencari arti dalam karya sastra (Abrams dalam Isnendes, 2018, hlm. 82).

Hal ini sesuai dengan pendapat Todorov (1985, hlm. 11) bahwa struktural berhubungan dengan kejadiankejadian bahasa. Todorov membagi struktural ke dalam tiga aspek, yaitu aspek sintaksis (alur), semantik (tema, tokoh, latar carita), dan verbal (sudut pandang).

\section{METODE}

Penelitian yang berjudul "Aspek Kepribadian Tokoh Utama dalam Kumpulan Cerpen Jurig Paséa jeung Nyi Karsih" karya Tini Kartini merupakan penelitian kualitatif dengan metode deskriptif analisis. Metode deskriptif analisis dilakukan dengan cara mendeskripsikan fakta-fakta, seterusnya dianalisis (Ratna, 2012, hlm. 53).
Metode deskriptif analisis mendukung kepada tujuan penelitian ini yang mendeskripsikan dan menelusuri aspek kepribadian tokoh utama dalam kumpulan cerpen Jurig Paséa jeung Nyi Karsih karya Tini Kartini.

Sumber data yang digunakan yaitu kumpulan cerpen Jurig Paséa jeung Nyi Karsih karya Tini Kartini. Kumpulan cerpen ini merupakan citakan pertama yang terbit pada tahun 2003, oleh penerbit Kiblat Buku Utama Bandung, dengan tebal 147 halaman.

Kumpulan cerpen Jurig Paséa jeung Nyi Karsih terdiri atas tiga kumpulan cerpen, yaitu kumpulan cerpen "Jurig", kumpulan cerpen "Paséa", dan kumpulan cerpen "Nyi Karsih". Kumpulan cerpen ini semuanya ada 16 judul.

Dalam penelitian ini, yang ditelusuri hanya dua kumpulan cerpen "Jurig" dan "Nyi Karsih", yang terdapat 12 judu 1 cerpen. Kumpulan cerpen "Paséa" tidak ditelusuri dalam penelitian ini, karena mempunyai komplekstas ceritanya saja, sedangkan kompleksitas tokohnya kurang.

Data dalam penelitian ini dikumpulkan dengan beberapa cara, yaitu teknik telaah pustaka dan teknik analisis secara langsung. Teknik telaah pustaka digunakan untuk mencari sumber-sumber teori kebutuhan referensi (teori struktural Todorov, psikologi sastra Jacques Lacan, dan faktor-faktor kapribadian). Teknik analisis secara langsung digunakan untuk mengolah data aspek kepribadian tokoh utama dalam kajian struktural dan psikologi sastra Lacan.

Instrumen penelitian yang digunakan yaitu tabel untuk mengumpulkan data dan kartu data analisis untuk mengolah data yang ada dalam kumpulan cerpen Jurig Paséa jeung Nyi Karsih. Instrumen mempunyai manfaat untuk membantu penelitian agar mendapatkan informasi yang dibutuhkan. Menurut Arikunto (2013, hlm. 203), instrumen penelitian yaitu alat atau 
fasilitas yang digunakan peneliti dalam mengumpulkan data agar lebih mudah dan bisa mendapatkan hasil yang baik, dalam arti lengkap dan sistematis sampai dengan bisa dianalisis.

\section{HASIL DAN PEMBAHASAN}

Konsep analisis 12 cerpen yang ada dalam kumpulan cerpenJurig Paséa jeung Nyi Karsih tidak jauh berbeda dengan cerpen lainnya, meskipun kepribadian tokoh utamanya mempunyai kepribadian yang tidak sama. Oleh karena itu, ada salah satu cerpen yang diambil sebagai contoh dalam pembahasan ini, yaiu cerpen "Nyi Karsih". Cerpen "Nyi Karsih" pernah disalin oleh Ajip Rosidi ke dalam bahasa Indonesia, terus disajikan dalam antologi Dua Orang Dukun. Bisa jadi hal itu menuduhkan bahwa cerpen "Nyi Karsih" sudah dinilai sebagai cerpen karangan Tini Kartini yang paling baik.

\section{Struktur Kumpulan Cerpen Jurig Paséa jeung Nyi Karsih}

Dalam analisis struktur kumpulan cerpen Jurig Paséa jeung Nyi Karsih, menggunakan teori Todorov, yang terdiri atas tiga aspek, yaitu aspek sintaksis (alur), aspek semantik (tema, tokoh, latar), jeung aspek verbal (sudut pandang).

Dari tigas aspek itu, yang ditelusuri hanya aspek sintaksis dan semantik kumpulan cerpen "Jurig" dan "Nyi Karsih" saja. Aspek verbalnya tidak ditelusuri, karena dalam penelitian ini sudut pandang tidak terlalu mempengaruhi terhadap hasil akhir dalam penelitian ini yang dihubungkan dengan psikologi sastra, tegasnya dalam aspek kepribadian tokoh utama.

\section{Aspek Sintaksis}

Alur dalam kumpulan cerpenJurig Paséa jeung Nyi Karsih dianalisis terlebih dahulu melewati proses pengaluran dengan cara menganalisis gagasan inti (fungsi utama), dan fungsi utama tersebut akan ditelusuri dengan cara menganalisis sekuen-sekuennya. Sekuen yaitu unsur paling terkecil di dalam isi cerita.

Dalam 12 cerpen yang dianalisis, yaitu cerpen "Jurig", cerpen "Surat", cerpen "Ondangan", cerpen "Ngiuhan", cerpen "Emang jeung Embi", cerpen "Leungit", cerpen "Emang jeung Alo", cerpen "Sial", cerpen "Study Club", cerpen "Di lembur", cerpen "Nyi Karsih", dan cerpen "Oom Noto", keseluruhan ada 410 sekuen dan 155 fungsi.

Sesudah dianalisis pengaluran, tahapan selanjutnya dianalisis alur. Menurut Nurgiyantoro(2013, hlm. 201), alur terbagi menjadi tiga tahapan, yaitu: awal, tengah, jeung ahir. Analisis alur dalam cerpen"Nyi Karsih" bisa dilihat dalam tabél 1.

Tabel 1 Skema Alur Cerpen "Nyi Karsih"

\begin{tabular}{|c|c|}
\hline Tahap & Cutatan \\
\hline \multirow{15}{*}{ Awal } & Nyi Karsih nu hirupna di alam \\
\hline & kota M masih kénéh \\
\hline & kabupatén, lain kawadanan \\
\hline & kawas ayeuna (tahap \\
\hline & ngawanohkeun) \\
\hline & Nya dina mangsa-mangsa \\
\hline & kabupatén icikibung na pésta \\
\hline & napsu héwani (tahap \\
\hline & rangsangan) \\
\hline & Nyi Karsih téh nya kitu waé \\
\hline & purah diutuh-étah ku agan, \\
\hline & sasapu atawa mérésan kamar \\
\hline & teu mundayan gé néangan \\
\hline & kutu, teu kitu mantuan Ma \\
\hline & Ani di dapur (tahap gawatan) \\
\hline \multirow{11}{*}{ Tengah } & Sakali mangsa manéhna \\
\hline & kungsi meunang kareuwas \\
\hline & anu lain lumayan ti Pa Jura, \\
\hline & panglebok Dalem (tahap \\
\hline & tikaian) \\
\hline & Dalem geus ngaraos bosen ku \\
\hline & selir anu araya, saurna téh \\
\hline & geus teu nimbulkeun birahi. \\
\hline & Gan Angga diancam ku \\
\hline & Dalem, mun teu meunang \\
\hline & $\begin{array}{l}\text { peuting engké rék dipecat } \\
\text { (tahap rumitan) }\end{array}$ \\
\hline
\end{tabular}




\begin{tabular}{ll}
\hline Tahap & \multicolumn{2}{c}{ Cutatan } \\
\hline & Nyi Karsih pada \\
& ngadangdanan. Peutingna, \\
& Nyi Karsih ngaliwat ka \\
& hareupeun panto kamarna \\
& nuturkeun Gan Angga lebet \\
& ka pangkuleman Dalem \\
& (tahap klimaks) \\
\hline & $\begin{array}{l}\text { Isukna, urang kabupatén } \\
\text { guyur Nyi Karsih leungit } \\
\text { (tahap leraian) }\end{array}$ \\
& $\begin{array}{l}\text { Saminggu ti harita, urang } \\
\text { Ahir } \\
\text { sasak landeuh gujrud } \\
\text { manggih mayit budak mojang } \\
\text { nyelap dina batu gedé (tahap } \\
\text { selesaian) }\end{array}$ \\
\hline
\end{tabular}

Pertama, tahap awal. Tahap awal sebuah cerita biasanya disebut tahap wawanohan, isinya mengenai informasi penting yang ada hubungannya dengan bermacam hal yang akan diceritakan seterusnya.

Kedua, tahapan tengah. Tahapan tengah cerita atau disebut tahapan pertikaian (konflik). Tahapan ini memperlihatkan pertengahan cerita dan konflik yang sudah dimunculkan pada tahap sebelumnya.

Ketiga, tahapan ahir sebuah cerita, biasanya disebut tahap peleraian, memperlihatkan kejadian-kejadian akibat dari klimaks cerita sebelumnya yang ada pada tahapan tengah.

\section{Aspek Semantik}

Tema

Tema merupakan inti pemikiran dalam sebuah cerita. Berdasarkan keutamaannya, tema terbagi menjadi dua, yaitu tema utama dan tema tambahan. Tema utama atau disebut dengan tema mayor yaitu tema yang mempunyai isi cerita inti. Makna yang ada dalam tema utama merupakan makna pokok cerita, yang terlihat dari banyaknya cerita, tegasnya bukan tema yang ada dalam satu bagian saja. Sedangkan makna yang hanya ada pada bagian-bagian cerita disebut tema tambahan atau tema minor (Nurgiyantoro, 2013, hlm. 83).

Tema mayor cerpen "Nyi Karsih" yaitu nasib buruk Nyi Karsih yang hidup di kabupaten sampai membunuh dirinya sendiri. Hal ini terlihat dalam keseluruhan isi cerita yang dominan menceritakan mengenai kehidupan Nyi Karsih di kabupaten. Sedangkan tema minornya yaitu: 1) Bupati $M$ yang mempunyai banyak selir; 2) Nyi karsih dibawa ka kabupaten; 3) harapan Ma Ani kepada Nyi Karsih; 4) Gan Angga membohongi Ma Ani; 5) Nyi Karsih dibawa ke kamar Dalam; 6) Nyi Karsih yang sudah tidak perawan; serta 7) Nyi Karsih kabur dari kabupaten.

Cerpen ini dilatarbelakangi oleh sejarah ketika jaman feodalisme masih ada. Juragan Dalem, yaitu Bupati di jaman sekarang, sudah dianggap seperti raja. Hal ini dibuktikan dengan adanya penyebutan pangawulaan, yang artinya tempat ngawula orang banyak. Hanya keinginannya yang harus dipenuhi pelayan serta rakyatnya.

\section{Tokoh jeung Penokohan}

Menurut Nurgiyantoro(2013, hlm. 176), tokohmempunyai peran penting dalam cerita, karena tokoh bisa menghidupkan isi cerita. Tokoh dalam karya sastra bisa terbagi menjadi beberapa bagian, di antaranya tokoh utama dan tokoh tambahan.

Dilihat dari fungsi tampilnya, tokoh bisa dibedakan menjadi tokoh protagonis dan tokoh antagonis. Dan dilihat dari jenis karakternya, ada tokoh basajan dan tokoh buleud.

Tini Kartini dalam mendeskripsikan karakter para tokoh secara langsung tidak bisa ditebak. Jadi, pembaca tidak langsung bisa menebak karakter para tokoh yang mempunyai karakter baik atau jahat. Tokoh-tokoh dalam setiap cerpen mempunyai karakter yang berbeda, hal ini menyebabkan rasa penasaran peneliti dalam menganalisis tokoh-tokohnya, dengan demikian bisa 
menghasilkan analisis aspek kepribadian. Misalnya dalam cerpen "Nyi Karsih", tokoh cerpen "Nyi Karsih" yaitu ada delapan tokoh, di antaranya: Nyi Karsih, Bupati/Dalem, Ma Ani, Indungna, Bapana, Pa Hasan, Pa Jura, dan Gan Angga.

Berdasarkan pada pemeranan tokoh, tokoh utama dalam cerpen "Nyi Karsih" yaitu Nyi Karsih, sedangkan tokoh tambahan yaitu Bupati/Dalem, Ma Ani, Indungna, Bapana, Pa Hasan, Pa Jura, dan Gan Angga. Dilihat dari fungsi tampilnya, tokoh protagonis yaitu Nyi Karsih, Ma Ani, Bapana, Indungna, dan $\mathrm{Pa}$ Hasan. Tokoh antagonis yaitu Bupati/Dalem, Pa Jura, dan Gan Angga. Serta dilihat dari jenis karakternya, tokoh buleud yaitu Nyi Karsih, karena mengalami perubahan karakter. Sedangkan tokoh basajan yaitu Ma Ani, Bapana, Indungna, Bupati/Dalem, $\mathrm{Pa}$ Hasan, Gan Angga, dan Pa Jura, karena tidak mengalami perubahan karakter.

Tokoh Nyi Karsih dalam cerpen ini, peribahasa sunda mengatakan "lir ibarat jandéla leutik" untuk melihat kenyataan sejarah masyarakat yang sangat luas. Dengan mendalami perjalanan tokoh Nyi Karsih, pembaca juga lebih mendalami kenyataan sejarah di suatu tempat dan jaman, meskipun pembaca tidak pernah mengalami jaman tersebut.

\section{Latar}

Latar atau setting berpusat pada pengertian tempat, hubungan waktu, dan lingkungan sosial tempat berlangsungnya peristiwa-peristiwa yang diceritakan (Abrams dalam Nurgiyantoro, 2013, hlm. 217).

Latar yang ada dalam kumpulan cerpenJurig Paséa jeung Nyi Karsih, tidak hanya latar tempat saja, tetapi juga terdiri atas latar waktu dan latar sosial. Dalam kumpulan cerpen ini, latar waktu maupun latar tempat sama-sama mendukung pada latar sosial yang dihubungkan dengan status sosial kehidupan.
Latar cerita yang ada dalam cerpen "Nyi Karsih" yaitu latar tempat, latar waktu, dan latar sosial. Latar yang ada pada cerpen "Nyi Karsih" keseluruhan ada 29 latar. Latar tempat ada dua belas, yaitu dikabupaten, papanggungan, rohangan pésta, pasisian, leuweung, di lembur, di dapur, di kamar, pangkuleman dalem, handapeun sasak karéta, di makam, dan kawadanan. Latar waktu ada sepuluh, yaitu harita, peuting, katilu taun, mangbulan-bulan, isuk, tilulas taun, tilu poé tilu peuting, sapeuting jeput, saminggu, dan baheula. Latar sosial yang berhubungan dengan status sosial pada cerpen "Nyi Karsih" yaitu Bupati/Dalem, purah nyangu, Patani, agan-agan, purah lalacuran, Selir, dan Guru Ngaji.

Hal ini memperlihatkan bahwa pada cerpen "Nyi Karsih" adanya status sosial manusia biasa, manusia yang lebih dari orang lain, dan kehidupan kabupaten dahulu yang mempunyai sistem seperti kerajaan. Yang termasuk status sosial golongan manusia biasa atau rendah yaitu purah nyangu, patani, dan purah lalacuran. Yang termasuk golongan manusia yang lebih dari orang lain yaitu agan-agan dan guru ngaji. Serta yang termasuk golongan keluarga kabupaten, yaitu Dalem/Bupati.

\section{Aspek Kepribadian Tokoh Utama dalam Kumpulan Cerpen Jurig Paséa jeung Nyi Karsih}

Teori psikologi sastra, khususnyaa psikoanalisis Jacques Lacan merupakan perkembangan dari teori psikoanalisis Sigmund Freud. Halnya psikoanalisis Sigmund Freud yang membahas mengenai bagaimana keadaan kejiwaan manusia, teori psikoanalisis Lacan lebih membahas mengenai proses perkembangan kejiwaan manusia.

Teori psikoanalisis Jacques Lacan dalam membentuk kepribadian, terdiri atas tiga aspek, yaitu yang nyata merupakan tempat (suatu tempat psikis, bukan tempat fisikal) di mana adanya 
penyatuan, karena itu, tidak adanya ketiadaan (absence), kehilangan, atau kekurangan; yang imajiner merupakan segala hal yang tidak bisa terpenuhi, di mana adanya kebutuhan yang tidak bisa dipuaskan; sedangkan yang simbolik merupakan hasrat keinginan untuk menutupi kekurangan yang ada pada aspek yang imajiner (Bracher, 2018, hlm. xv). Hal ini sesuai dengan cerita yang dialami oleh para tokoh utama dalam kumpulan cerpenJurig Paséa jeung Nyi Karsih karya Tini Kartini, khususnya cerpen"Nyi Karsih".

\section{Aspek Kepribadian yang Nyata}

Kebutuhan Nyi Karsih dalam aspek ini, Nyi Karsih mempunyai peran sebagai tokoh perempuan yang masih perawan dengan mempunyai keluarga yang lengkap atau masih mempunyai orangtua dan adik-adiknya.

Kebutuhan Nyi Karsih dalam belajar juga dipenuhi oleh dirinya sendiri, ketika Nyi Karsih rajin belajar mengaji kepada Pa Hasan. Hal ini dibuktian dengan dialog sebagai berikut.

\begin{abstract}
Mun ti Peuting diajar ngaji di Pa Hasan tatangga landeuheun imahna. Leket ngajina mah, solatna getol, saregep kana sagala caritaan ustadna. Di lelewek lembur éta mah kaasup pangcalakanana waé.

(Kalau dari malam belajar mengaji di $\mathrm{Pa}$ Hasan tetangga dekat rumahnya. Rajin mengaji, solatnya rajin, semangat pada segala cerita ustadznya. Di tempat tinggalnya termasuk orang yang sangat pintar)
\end{abstract}

Hal itu menggambarkan bahwa kepribadian Nyi Karsih dalam aspek kepribadian yang nyata yaitu kepribadian Nyi Karsih yang rajin mengaji.

\section{Aspek Kepribadian yang Imajiner}

Selain Nyi Karsih mempunyai kebutuhan berdasarkan pada aspek kepribadian yang nyata sebelumnya. Nyi Karsih dan keluarganya mempunyai kekurangan dalam hal ekomoninya. Hal ini dibuktikan dalam dialog di bawah.

\begin{abstract}
Ma Ani ngarasa dosa, manéhna lubak-libuk sorangan nu di lembur kalaparan. Nya nyelang heula balik. Ceuk ajamanana barudak rék dibawa, saeutikna tilu mah, nu galedé tangtu marilu.

(Ma Ani merasa berdosa, mereka (keluarga adiknya) kelaparan di tempat tinggalnya. Berkesempatan pulang. Berniat anakanaknya akan dibawa, paling sedikit tiga orang, yang sudah besar pasti ikut.)
\end{abstract}

Kekurangan itu pun, dikuatkan oleh tokoh Bapanya Nyi Karsih yang bicara bahwa dirinya tidak sanggup memberi makan anaknya karena kahidupan ekonomi yang kurang.

Nya jung waé atuh, di lembur gé teu kaparaban.

(Silahkan, di sini juga tidak mampu untuk dikasih makan)

Kekurangan yang dialami oleh keluarga Nyi Karsih, menyebabkan Nyi Karsih dipaksa pergi oleh Ma Ani ke kabupaten untuk merubah kehidupan keluarga Nyi Karsih. Sejak saat itu, Nyi Karsih tinggal di kabupaten dengan Ma Ani.

\begin{abstract}
Mulangna deui ka dayeuh Ma Ani ukur bisa mawa Si Cikal. Kitu gé meunang maksa ngaririhan, ngolo jeung bari nyeukseukan. Éra pajar téh geus kagedéan, tilulas taun, tacan lakian.

(Pulangnya dari kota Ma Ani hanya bisa membawa anak pertama paling besar. Itu pun dipaksa, harus dirayu. Malu karena sudah besar, tiga belas tahun belum bersuami.)
\end{abstract}

Kekurangan Nyi Karsih juga yaitu mudah untuk dibohongi dengan Uwanya oleh Gan Angga, ketika Gan Angga janji kepada Nyi Karsih bahwa Nyi Karsih akan dijadikan selir Dalem. Hal ini dibuktikan oleh dialog sebagai berikut.

\footnotetext{
Antukna ngait Nyi Karsih nu deukeut. Bébéja ka uwana mah rék disenangkeun, dironjatkeun darajatna, dijieun puputon sekar kadaton. Ngomong kituna bari ngeupeulan duit hérang pangaji saimaheun mun di lemburna mah. Dilélér sumping jeung baju urut Juragan istrina, aralus kénéh bubuhan urut gé panganggo ménak.
} 
(Akibatnya ke Nyi Karsih yang dekat. Cerita kepada Uwanya akan dibahagiakan, ditingkatkan derajatnya, dibuat seperti putri di keratin. Cerita seperti itu sambil memberi uang. Diberi samping dan baju bekas Juragan istri, masih bagus bekas digunakan menak)

Sampai pada waktunya, Nyi Karsih masih belum mengetahui bahwa dirinya akan perlakukan bagaimana.

Badé dikumahakeun abdi téh Agan, bade dikamanakeun? Ararisin dikieu-kieu. Hoyong diwidian wangsul ka dapur, ka kobong Étéh Ema.

(Mau diperlakukan bagaimana saya Agan, mau dikemanakan? Malu seperti ini. Mohon diizinkan untuk pulang ke dapur, ke rumah Eteh Ema.)

Hal ini menggambarkan bahwa dalam aspek kepribadian yang imajiner, Nyi Karsih mempunyai kepribadian mudah dibohongi.

Sesudah Nyi Karsih dipaksa untuk 'menemani' Dalem, sudah tiga hari tiga malam Nyi Karsih tidak makan. Matanya sayu, wajahnya pucat, bibirnya kering. Kerjaan Nyi Karsih hanya melamun.

\section{Aspek Kepribadian yang Simbolik}

Hasrat keinginan Nyi Karsih untuk menutupi kekurangan pada aspek yang imajiner, yaitu dengan cara Nyi Karsih pergi bersama Uwanya Ma Ani untuk menutupi kekurangan ekonomi keluarganya.

Saat itu, ketika Nyi Karsih mudah dibohongi oleh Gan Angga, karena dijadikan selir Dalem, yang mengakibatkan Nyi Karsih sudah tidak perawan. Untuk menutupi rasa kecewanya dan sakit hatinya, Nyi Karsih kabur dari kabupaten, secara tidak langsung Nyi Karsih mempunyai kepribadian pasrah. Hal ini dibuktikan dalam kutipan cerita berikut.

Sakolébatan kacaangan ku cahya kilat, di juru émpang beulah kidul, katénjo ramoramo lalentik nyuaykeun pager kawat moncorkeun awakna nu ribeg ku hujan. Tiluy nyasar pager tukang, leumpang rumanggieung muru guruhna walungan caah.

(Petir, di pojok danau sebelah selatan, terlihat jari-jari membuka pagar kawat menerobos badannya yang basah oleh hujan. Terus menyusuri pagar belakang, jalan menuju sungai.)

Keesokan harinya, masyarakat kabupaten ramai dengan berita menghilangnya Nyi Karsih. Ma Ani hanya bisa menyesali terhadap perbuatannya yang tidak bisa menjaga Nyi Karsih. Akhir cerita, Nyi Karsih memilih jalan untuk menutupi kekurangannya dengan cara mencelakai diri sendiri.

Saminggu ti harita, urang sasak landeuh gujrud manggih mayit budak mojang nyelap dina batu gedé, handapeun sasak karéta. Mayit bungkang, bauna enggeus nyambuang. Taya nu nyaho mayit saha, iwal urang kabupatén.

(Seminggu semenjak itu, orang jembatan di sana gempar karena menemukan mayat anak perempuan terselip di batu besar di bawah jembatan kereta. Mayat, baunya yang sudah tercium. Tidak ada yang tahu mayat siapa, kecuali orang kabupaten.)

Sekarang kabupaten sudah bukan kabupaten lagi, tapi kota yang sepi kurang penghuni.

\section{Faktor Kepribadian Tokoh Utama dalam Kumpulan Cerpen Jurig Paséajeung Nyi Karsih}

Faktor yang mempengaruhi kepribadian para tokoh utama dalam kumpulan cerpenJurig Paséa jeung Nyi Karsih, yaitu ada dua faktor yang terdiri atas faktor internal dan faktor eksternal. Faktor internal banyak berhubungan dengan keadaan psikologis serta permasalahan hidupnya. Sedangkan faktor eskternal yaitu faktor yang ada di luar dirinya, seperti faktor lingkungan.

Berdasarkan pada aspek kepribadian Nyi Karsih yang sudah dianalisis sebelumnya, ada faktor-faktor yang mempengaruhi Nyi Karsih yaitu faktor internal Nyi Karsih yang pasrah, disebabkan oleh adanya keadaan psikologis yang sudah terganggu oleh 
banyaknya permasalahan hidupnya. Faktor Nyi Karsih yang mudah dibohongi oleh Gan Angga, hal ini berhubungan dengan permasalahan hidupnya yang sudah menjadi kepribadian Nyi Karsih yang 'polos'. Begitu pun dalam faktor eksternal, yaitu kepribadian Nyi Karsih yang rajin mengaji, disebabkan oleh adanya faktor lingkungan di tempat tinggalnya dengan adanya guru mengaji yaitu Pa Hasan.

\section{SIMPULAN}

Jurig Paséa jeung Nyi Karsih merupakan kumpulan cerpen yang membahas mengenai kompleksitas kepribadian tokoh dan konflik alur yang banyak dipermasalahkan dengan kehidupan jaman dahulu.

Struktur cerita yang ditelusuri hanya aspek sintaksis dan semantiknya saja. Hasil analisis terlihat jalan cerita berupa peristiwa-peristiwa yang dialami oleh para tokoh dan mengetahui klimaksnya cerita ini, yang akan berhubungan dengan analisis struktur seterusnya. Pembahasan dalam bagian hasil penelitian, tema dibagi menjadi dua yaitu tema mayor dan tema minor. Tokoh dianalisis berdasarkan perannya, tampilnya, dan karakternya. Latar cerita yang ada dalam cerpen "Nyi Karsih" keseluruhan ada 29 latar, di antaranya, di kabupaten, papanggungan, rohangan pésta, pasisian, leuweung, di lembur, dsb.

Tokoh-tokoh yang dianalisis aspek kepribadiannya yaitu tokoh utamanya saja. Dalam tiga aspek kepribadian yang sudah dibahas dalam hasil penelitian, aspek yang nyata, umumnya para tokoh utama mempunyai kebutuhan yang banyak terpenuhi oleh tokoh lainnya atau dirinya sendiri. Aspek yang imajiner, para tokoh utama mempunyai keinginan yang tidak sesuai dengan yang diharapkan, sampai terjadi rasa kekurangan dalam diri tokoh utama, Terakhir, aspek yang simbolik, para tokoh utama memunculkan hasrat keinginannya untuk dipenuhi dalam segala kekurangan yang terasa oleh para tokoh utama. Berdasarkan aspek kepribadian ini, Nyi Karsih mempunyai kepribadian yaitu yang pasrah, yang mudah dibohongi, dan yang rajin mengaji.

Hal ini dibuktikan dengan adanya faktor-faktor yang mempengaruhi kepribadian Nyi Karsih yaitu adanya faktor internal dan faktor eksternal. Faktor internal berhubungan dengan keadaan psikologis dan permasalahan hidupnya. Sedangkan faktor eksternal berhubungan dengan faktor keadaan di luar dirinya, yaitu faktor lingkungan.

\section{UCAPAN TERIMA KASIH}

Penulis mengucapkan syukur kepada Allah Swt., dan terima kasih kepada orang tua, serta semua pihak yang telah mendukung penuh sampai penelitian ini selesai. Semoga penelitian ini bermanfaat bagi pembaca.

\section{CATATAN PENULIS}

Penulis menyatakan bahwa tidak ada konflik kepentingan terkait publikasi artikel ini. Penulis mengkonfirmasi bahwa data dan artikel ini bebas plagiarisme.

\section{PUSTAKA RUJUKAN}

Arikunto, S. (2013). Prosedur Penelitian: Suatu Pendekatan

Praktik. Jakarta: Rineka Cipta.

Bracher, M. (2018). Jacques Lacan, Diskursus dan Perubahan Sosial: Pengantar Kritik-Budaya Psikoanalisis. Yogyakarta: Jalasutra.

Faruk. (2013). Pengantar Sosiologi

Sastra: dari Strukturalisme

Genetik sampai Post-Modernisme.

Yogyakarta: Pustaka Pelajar.

Isnendes, R. (2018). Teori Sastra

Kontemporer (Formalisme, Strukturalisme, dan Semiotika). Bandung: UPI Press.

Isnendes, R., \& Ucu Firmansyah. 
(2013). Masyarakat Sunda dalam Sastra: Komparasi Moralitas dan Kepribadian. Lokabasa. 4(1). Retrieved fromhttp://ejournal.upi.edu/index. php/lokabasa/article/viewFile/312 8/2149.

Jusriani. (2015). Konflik Tokoh dalam Novel Rindu Karya Tere Liye (Tinjauan Psikologi Sastra). Humanika, 3(No. 12). Retrieved from

http://garuda.ristekdikti.go.id/auth or/view/561804.

Kartini, T. (2003). Jurig Paséa jeung Nyi Karsih. Bandung: Kiblat Buku Utama.

Lechte, J. (2001). 50 Filsuf Kontemporer. Yogyakarta: Kanisius.

Minderop, A. (2016). Psikologi Sastra: Karya Sastra, Metode, Teori, dan Contoh Kasus (Yayasan Pu). Jakarta.

Nurgiyantoro, B. (2013). Teori Pengkajian Fiksi. Yogyakarta: Gadjah Mada University Press.

Rakhman, F. (2013). Cerita Wayang
Rahwana Pejah Garapan Asep Sunandar Sunarya (Kajian Struktur dan Psikologi Sastra). Lokabasa, 4(2), 101-111. https://doi.org/10.17509/jlb.v4i2.3 130.

Ratna, N. K. (2012). Penelitian Sastra: Teori, Metode, dan Teknik. Yogyakarta: Pustaka Pelajar.

Sumarwati, J., \& Raheni, S. (2012). Konflik Batin Tokoh-Tokoh dalam Kumpulan Cerita Madre Karya Dewi Lestari. BASASTRA, Vol 1(No. 1). Retrieved from https://eprints.uns.ac.id/1172/1/20 78-4685-1-SM.pdf.

Todorov, T. (1985). Tata Sastra. Jakarta: Djambatan.

Wiyatmi. (2011). Psikologi Sastra (Teori dan Aplikasinya). Yogyakarta: Kanwa Publisher.

Zaelani, T. (2015). Aspék Kapribadian dina Novélét Catetan Poéan Réré ( Cpr ) Karya Ai Koraliati. Dangiang Sunda, 5(3), 1-10. Retrieved from http://antologi.upi.edu/file/Jurnal_ Indonesia_5.pdf. 